\title{
Left Ventricular Function in Patients with Rheumatic Mitral Stenosis
}

\author{
Sudeb Mukherjee* \\ Department of Cardiology, ICVS, IPGME\&R-SSKM Hospital, India
}

Submission: July 13, 2018; Published: August 21, 2018

*Corresponding author: Sudeb Mukherjee, Department of Cardiology, ICVS, IPGME\&R-SSKM Hospital, Kolkata-700020, India, Tel: 91- 8334014941; Email: drsumukherjee@gmail.com

\section{Abstract}

Left Ventricular (LV) function remain unchanged in large number of patients with Mitral Stenosis (MS). Echocardiographic assessment with M mode often fails to detect such changes. Other imaging methods and/or modalities might detect such abnormalities which may affect patient outcomes. LV functional impairment has been seen in certain percentage of patients even with isolated pure MS.

Keywords: Left ventricular ejection fraction (LVEF); Mitral stenosis (MS)

Abbreviations: LV: Left Ventricular; MS: Mitral Stenosis; LVEF: Left Ventricular Ejection Fraction; MR: Mitral Regurgitation; LVEDP: Left Ventricular End Diastolic Pressure; EF: Ejection Fraction; TDI: Tissue Doppler Imaging; PBMV: Percutaneous Balloon Mitral Valvotomy

\section{Introduction}

The most common pathophysiologic cause of Mitral Stenosis (MS) is rheumatic disease [1]. Generally Left Ventricular (LV) systolic function is well preserved in isolated MS. LV chamber typically is normal or small. However, coexisting Mitral Regurgitation (MR), aortic valve disease, ischaemic heart disease, systemic hypertension, cardiomyopathy all may be responsible for elevation of Left Ventricular End Diastolic Pressure (LVEDP) [2]. Left Ventricular (LV) dysfunction has been described in pure Mitral Stenosis (MS), which may be a due to change in interaction between right and left ventricles, myocardial fibrosis or a chronic decrease in preload [3]. Even with normal ejection fraction (indicating preserved global left ventricular function), there can be impairment in long-axis function (measured by tissue Doppler echocardiography) [4]. Altered LV long-axis movement has been shown to be a sensitive indicator of early myocardial dysfunction. Atrial fibrillation has shown to cause impairment of LV function. Pulsed-wave Doppler tissue velocities have been proven to be a good tool for assessment of long-axis ventricular shortening and lengthening. In the echocardiographical assessment of LV function, the Ejection Fraction (EF), Tissue Doppler Imaging (TDI), Doppler strain, and 2D strain have been widely used [5]. EF is the most widely used index of contractile function, but due to the visual component, assessment of endocardial excursion is subjective and has high inter-observer variability [6]. TDI and Doppler strain are characterized by limitations of angle dependence, limited spatial resolution and deformation analysis in one dimension [7]. 2D strain is a novel technique which evaluates LV systolic functions more objectively and quantitatively, and does not have the limitations seen in EF, TDI, and Doppler strain; thus, it has become more commonly used in recent years [8]. In the diagnosis of LV dysfunction due to MS, some studies have shown EF, TDI, and Doppler strain to be useful however there is paucity of data. There are also very few studies combining both conventional and 2D strain echo for evaluation of LV systolic function after successful Percutaneous Balloon Mitral Valvotomy (PBMV). There are also lack of evidences comparing LV systolic function before and after the above-mentioned procedure in patients with severe rheumatic MS.

\section{Review of Literature}

The existence of LV dysfunction in a quarter of patients with MS has been shown in many studies [9]. Many hemodynamic and myocardial factors have been put forward regarding the $\mathrm{LV}$ dysfunction in MS, including reduction in LV filling, chronic myocardial inflammation, scarring of sub valvular apparatus, reduction of $\mathrm{LV}$ compliance and diastolic dysfunction, increased afterload, abnormal right-left septal interaction, and pulmonary hypertension [10]. A study by Sengupta et al. [11] showed that mitral annular velocities measured by TDI immediately improved after percutaneous mitral balloon valvuloplasty, but not EF, and this improvement correlated with the changes in MVA. This 
finding leads to the consideration that systolic dysfunction in MS depends on myocardial factors rather than hemodynamic factors [11]. Similarly, a unique electron microscopy study in pure MS patients by Lee et al. [12] showed that regardless of LV function, varying degrees of ultrastructural pathologic changes occurred in myocardial muscle cells in all examined specimens (myocardial factor), but these impairments did not correlate with the severity of MS. In addition, those patients with abnormal LV function always exhibited more extensive loss of myofibrils. Both of these studies have shown that LV systolic dysfunction in MS is dependent on myocardial factors rather than hemodynamic factors [12].

\section{Discussion}

Although there is a downward trend in the prevalence of Mitral Stenosis (MS) in developed countries, it stands out as a huge public health problem in developing countries. It is accepted that isolated MS does not impair Left Ventricular (LV) systolic function, but in some publications, it has been shown that MS impairs LV systolic function. In the assessment of LV systolic function, a number of imaging techniques - such as echocardiography, MRI, Scintigraphy and CT scan - have been used. In the echocardiographical assessment of LV function, the Ejection Fraction (EF), Tissue Doppler Imaging (TDI), Doppler strain, and 2D strain have been widely used. The presence of impaired LV systolic function determined by M-mode and/or two-dimensional echocardiography was noted only in $25-30 \%$ of patients with MS. Conventional echocardiographic parameters are not able to demonstrate subclinical LV dysfunction in patients with MS. Therefore two-dimensional (2D) strain and strain rate imaging should be considered for the quantitative assessment of global and segmental LV function from 2D images.

\section{References}

1. Chambers JB, Bridgewater B (2013) Epidemiology of valvular heart disease. In: Otto CM \& Bonow RO (Eds.), Valvular heart disease: A
Companion to Braunwald's Heart Disease: (4 ${ }^{\text {th }}$ edn). Philadelphia, Saunders, USA, pp. 1-13.

2. Cengiz B, Şahin ŞT, Yurdakul S, Kahraman S, Bozkurt A, et al. (2018) Subclinical left ventricular systolic dysfunction in patients with severe aortic stenosis: A speckle-tracking echocardiography study. Turk Kardiyol Dern Ars 46(1): 18-24.

3. Gash AK, Carabello BA, Cepin D, Spann JF (1983) Left ventricularejection performance and systolic muscle function in patients with mitral stenosis. Circulation 67(1): 148-154.

4. Ozer N, Can I, Atalar E, Sade E, Aksöyek S, et al. (2004) Left ventricular long-axis function is reduced in patients with rheumatic mitral stenosis. Echocardiography 21(2): 107-112.

5. Thomas G (2007) Response to non-Doppler two-dimensional strain imaging echocardiography-from technical considerations to clinical applications. J Am Soc Echocardiography 20(8): 1020.

6. Liu CP, Ting CT, Yang TM, Chen JW, Chang MS, et al: (1992) Reduced left ventricular compliance in human mitral stenosis: role of reversible internal constraint. Circulation 85(4): 1447-1456.

7. Marwick TH (2006) Measurement of strain and strain rate by echocardiography: ready for prime time? J Am Coll Cardiol 47(7): 1313-1327.

8. Heller SJ, Carleton RA (1970) Abnormal left ventricular contraction in patients with mitral stenosis. Circulation 42(6): 1099-1110.

9. Mohan JC, Khalilullah M, Arora R (1989) Left ventricular intrinsic contractility in pure rheumatic mitral stenosis. Am J Cardiol 64(3): 240-242.

10. Klein AJ, Carroll JD (2006) Left ventricular dysfunction and mitral stenosis. Heart Fail Clin 2(4): 443-452.

11. Sengupta PP, Mohan JC, Mehta V, Kaul UA, Trehan VK, et al. (2004) Effects of percutaneous mitral commissurotomy on longitudinal left ventricular dynamics in mitral stenosis: quantitative assessment by tissue velocity imaging. J Am Soc Echocardiogr 17(8): 824-828.

12. Lee YS, Lee CP (1990) Ultrastructural pathological study of left ventricular myocardium in patients with isolated rheumatic mitral stenosis with normal or abnormal left ventricular function. Jpn Heart J 31(4): 435-448.

\section{Your next submission with Juniper Publishers} will reach you the below assets

- Quality Editorial service

- Swift Peer Review

- Reprints availability

- E-prints Service

- Manuscript Podcast for convenient understanding

- Global attainment for your research

- Manuscript accessibility in different formats

( Pdf, E-pub, Full Text, Audio)

- Unceasing customer service

Track the below URL for one-step submission https://juniperpublishers.com/online-submission.php 